\title{
7
}

\section{Formal and Informal Care in the Public and Private Spheres in England and Australia}

\author{
BRIAN SLOAN ${ }^{*}$ \\ I. Introduction: The Conundrum of Space \\ and Formal, Informal, Public and Private Care
}

Any attempt to distinguish between public and private spheres as spaces of care gives rise to immediate difficulties. This is true not least because it is necessary also to distinguish between formal care, provided pursuant to a contractual or other legal duty, and informal care, provided in the absence of such a duty. For example, while formal social care tends to be associated with public responsibility and the state, in England 'few local authorities are now involved in the direct delivery of care and support services', with most services operated by private, for-profit providers (Kelly 2013: 24). ${ }^{1}$ Much formal care takes place in private homes, and such homes and other private property can be appropriated to fund the social care system. Moreover, privacy must be an important value in the context of a care home that might in other respects be characterised as public (Hughes 2004). Conversely, the recognition of, not to mention reliance on, informal care (which might legitimately be characterised as a matter of private arrangement, albeit inherently informal) by

\footnotetext{
* This chapter builds upon research that I undertook while a doctoral student, an Early Career Fellow at CRASSH in Cambridge, and an Academic Visitor at the University of New South Wales. I am grateful for the Fellowship, funding from the Society of Legal Scholars and the Cambridge Humanities Research Grant Scheme and the support of, among others, Kevin Gray, Jens Scherpe, Daniel Joyce, Isabella Alexander and Wendy Schrama. Comments were gratefully received from attendees of seminars at UNSW, the University of Technology, Sydney and the Molengraaff Instituut voor Privaatrecht in Utrecht. The aim has been to state law, policy, financial values, etc, correct as of 25 September 2018.

${ }^{1}$ See also Robertson et al (2014: 19), albeit that most providers in Australia are apparently nonprofit. The common theme with Dominey and Gelsthorpe's chapter in this volume (Chapter 3) is noteworthy.
} 
the state arguably gives it a public character, and the social care system on occasion turns informal carers into care workers through mechanisms such as direct payments (Ungerson 2004). There is also an important distinction between public and private law, with the former encompassing claims against the state by one or more individuals and the latter encompassing claims by one or more private individuals against another such individual or group. The concepts of public and private therefore cut across the economy of care.

Mindful of these difficulties, this chapter will focus on the relationship between formal (associated with the public sphere) and informal (associated with the private sphere) care in England and Australia, in terms of their legal recognition and funding. It will highlight the fact that, while both formal systems have recently moved towards limiting the liability of care recipients to pay for their formal care (albeit very tentatively in England), several parts of Australia have been much more willing to facilitate the rational recognition of informal caring relationships in private law than has been the case in England, with the result that property transfers can be mandated between care recipients (generally via their estates) and informal carers. The chapter will consider whether approaches to the funding of formal care can be squared with the recognition of informal care in private law.

\section{Formal Care}

\section{A. England}

Adult social care is the responsibility of local authorities in England. While it lacks a statutory definition, it has been said that it supports people of all ages with certain physical, cognitive or age-related conditions in carrying out personal care or domestic routines' (Commission on Funding of Care and Support 2011: 4). It is distinct from health care provided by the National Health Service (NHS), which is designed to 'secure improvement' 'in the physical and mental health of the people of England'3 and 'in the prevention, diagnosis and treatment of physical and mental illness. ${ }^{4}$ This distinction assumes particular importance as regards the funding of care, but is frequently criticised (Herring 2016: 54).

The charging regimes for health care and social care have been separate since the beginnings of the NHS (Bilton 2014: 14). The National Health Service Act 2006 mandates that ' $\mathrm{t}$ ] he services provided as part of the health service in England must be free of charge' except where legislation expressly provides otherwise. ${ }^{5}$

\footnotetext{
${ }^{2}$ National Health Service Act 2006, s 1(1).

${ }^{3}$ National Health Service Act 2006, s 1(1)(a).

${ }^{4}$ National Health Service Act 2006, s 1(1)(b).

${ }^{5}$ National Health Service Act 2006, s 1(4).
} 
By contrast, however, the Dilnot Commission on the Funding of Care and Support (2011: 11) explained that '[v]ery broadly, under [the social care] system, people with assets over $£ 23,250$ receive no financial state support and need to fund their own care' and ' $\mathrm{t}$ ] he level and type of state support for people with assets below this threshold depends on their needs and income'. A care recipient's liability to pay is assessed by a local authority (separately to a needs assessment) ${ }^{6}$ using an extremely complex set of regulations to determine the existence of relevant capital and income. ${ }^{7}$ Baxter (2016) estimated that in the recent past between 20 and 25 per cent of those receiving care in their own homes, and between 43 and 45 per cent of those doing so in a care home, paid for their own care, as well as predicting future increases in those figures.

The starkness of the funding differences is not, however, reflected in the distinction between the types of care (Spencer-Lane 2015: [1-268]). There is also controversy over NHS Continuing Healthcare:

[A] package of ongoing care ... arranged and funded solely by the [NHS] for individuals outside a hospital setting who have complex ongoing healthcare needs, of a type or quantity such that they ... have a 'primary health need' ... as a result of disability, accident or illness (Department of Health 2018: [15.33]). ${ }^{8}$

The King's Fund (2014: 3) describes NHS Continuing Healthcare (with its very stringent criteria) as involving an 'all or nothing' assessment, whereby those who pass it receive free care and accommodation.

Mayhew and Smith (2014: 670-71) emphasise that '[a] ... system for funding social care ... along similar lines to the NHS ... would involve a combination of higher taxes, more borrowing and/or redirecting public finances from other priority areas', at a time of a perceived need for austerity and in which local authorities are already struggling to meet demands (Age UK 2016) and the dignity of those who require care is far from guaranteed, whatever the rhetoric surrounding the introduction of the Care Act 2014 (Sloan 2016). Even so, the King's Fund (2014: vi) asserts that pressures in health and social care and the needs of an ageing population 'call for a response that goes well beyond patching up existing services and making the changes set out in the Dilnot report [involving the capping of liability]'. The Fund makes the bold claim that 'higher public spending on health and social care is affordable if it is phased in over a decade' and recommend that it be funded 'through tax and national insurance increases, reallocating funds from other areas of spending, and changes to prescription charges'. For the time being, however, the marked distinction between the funding arrangements for health and social care looks set to stay.

\footnotetext{
${ }^{6}$ Care Act 2014, ss 9-13.

${ }^{7}$ Care and Support (Charging and Assessment of Resources) Regulations, SI 2014/2672, made under Care Act 2014, ss 14 and 17, inter alia.

${ }^{8}$ See National Health Service Commissioning Board and Clinical Commissioning Groups (Responsibilities and Standing Rules) Regulations SI 2012/2996, Part 6.
} 
The charging and funding regime in the Care Act 2014 was nevertheless 'intended to make charging fairer and more clearly understood by everyone' (Department of Health 2018: [8.2]). Hopkins and Laurie (2015: 112) describe it as 'a significant rebalancing of the individual-state relationship in terms of responsibility for funding ... social care, whilst maintaining the underlying model of funding through both individual and state contributions'.

Under the regime that would have been introduced via the Care Act 2014, based somewhat on the Dilnot Commission's proposals but then delayed by the Government until 2020 before being scrapped (BBC News 2017), people with assets of $£ 118,000$ (where the person's home is included in the financial assessment; the figure was $£ 27,000$ otherwise) would start to receive help with care costs (Department of Health 2015: [9.7]). £17,000 would have been the new lower limit of the means test below which no contribution will be expected from the individual (Department of Health 2015: [9.8]), increased from $£ 14,250 .{ }^{9}$

The lifetime cap on an individual's social care contributions was a central aspect of the Dilnot proposals and the Act. ${ }^{10}$ It was expected to be $£ 72,000$ for those developing eligible care needs after the age of 25 if it was first introduced in April 2016 (Department of Health 2015: [10.2]), and it would have been adjusted annually to account for inflation. ${ }^{11}$ The effect of the cap would have been limited, however. Even before its implementation was delayed, the King's Fund (2014: 3) emphasised that only the cost of meeting eligible needs would count towards the cap, which are likely to be critical or substantial and not low or moderate. There was also concern that progress towards the cap could be set below what it costs an individual to pay for care (Department of Health 2015: chapter 4) because the local authority could secure cheaper provision itself (Spencer-Lane 2015 [1-317]). It should also be emphasised that the cap would exclude so-called 'general' or 'daily' 'living costs' within a care home, and these were expected to be set at around $£ 12,000$ per year (Department of Health 2015: [7.3]; Fernández and Nadash 2016). These limitations on the cap would have left many people paying a considerable sum towards their care even if the cap were brought into effect (Institute and Faculty of Actuaries 2015). For example, the Institute and Faculty of Actuaries (2014) has estimated that those who reached the cap would have spent an average of $£ 140,000$ before doing so, and that only around 10 per cent of those who pay for care would ever reach it (Independent Age and Institute and Faculty of Actuaries 2017). As a consequence, it recommends an inclusive $£ 100,000$ cap that includes the local authority rate, daily living costs and 'excess' top-up fees based on average care costs.

Aside from the cap, a major area of funding reform within the Care Act relates to the offering of deferred payment agreements (DPAs), allowing the payment of

\footnotetext{
${ }^{9}$ National Assistance (Assessment of Resources) Regulations SI 1992/2977, r 28(1).

${ }^{10}$ Care Act 2014, s 15.

${ }^{11}$ Care Act 2014, s 16.
} 
social care costs to be deferred (via a secured loan) until a point such as the death of the care recipient or the sale of her home. ${ }^{12}$

The Government hoped that a market in insurance products would develop once the cap came into effect, to help people pay for care (Department of Health 2014). The King's Fund (2014: vi), however, claimed that there were 'no signs' that such a market would develop. Mayhew and Smith (2014: 670) express concern that ' $[\mathrm{i}] \mathrm{f}$ spending by the state and by the individual does not keep pace with need, ... the quality and availability of care will suffer unless there are better mechanisms to help people support themselves. ${ }^{13}$ An extra $£ 2$ billion for social care was pledged by the Chancellor in 2017 , and a further $£ 150$ million was announced by his successor the following year, but there are concerns that this remains insufficient to improve the level of care appropriately and cope with increased demand (Campbell 2017; Walker 2018).

The future of the funding of social care remains in doubt following the 2017 general election. In fact, the Conservative manifesto (Conservatives 2017) proposed to remove the 'disregard' preventing a person's home being included in the assessment where she is to receive care in her own home. The objective was said to be increasing fairness in the system while also assisting it to cope with increased demands as a result of the ageing population. This would have meant some people currently receiving free care being expected to pay for it in future, but would have been offset by an increase in the current $£ 23,250$ threshold to $£ 100,000$ (which local authorities have indicated they are unable to afford: Elgot 2017). The aim was expressed to be to ensure that self-funders would have $£ 100,000$ to pass on via inheritance. The cap was not mentioned in the manifesto at all, although the then Prime Minister Theresa May later indignantly asserted that there would be such a cap without specifying what it would be (Asanthana 2017). Following the Conservatives' failure to secure an overall majority in the House of Commons, the Queen's Speech (HM Government 2017) covered social care in a rather 'light touch' manner: all that is really known is that proposals will be brought forward for consultation via a Green Paper, which will apparently not now be published until autumn 2018 (Jarrett 2018). It was announced in December 2017 that the cap planned for 2020 would not be brought forward, albeit that some form of limitation on liability to pay is still apparently planned (BBC News 2017).

The reality is that, pending any further reform, a significant portion of the population in England will have to pay a considerable sum towards their care, not least since the average annual cost of a care home in December 2017 was exceeding $£ 40,000$ if nursing care is necessary (Paying for Care). This could have significant implications for any recognition of informal care in private law, discussed in

\footnotetext{
${ }^{12}$ The DPA prima facie falls due for repayment 90 days after the person's death or on disposal of property on which the local authority has a charge: Department of Health (2018: [9.108]; Care and Support (Deferred Payment) Regulations SI 2014/2671, r 7.

${ }^{13}$ They therefore propose Personal Care Savings Bonds.
} 
the next section. More broadly, it perpetuates a form of discrimination between people with different types of care need, even if that is not actionable, and can produce situations where the system fails fully to meet the needs of a social care recipient in a manner consistent with her dignity, and charges her catastrophically for the privilege of enduring that failure (Sloan 2016). The potential undesirability of the extent of the current 'user pays' principle must, however, be seen in the context of the fact that any reduction in the amount going into the system might prejudice its ability to meet the needs of those who genuinely cannot afford to pay for their care, particularly since a considerable care funding shortfall for the future has already been predicted. The next sub-section analyses the funding of formal social care in Australia.

\section{B. Australia}

Australia is dealing with similar demographic issues to England, and an independent report (Tune 2017: 7) has said that 'there is a need for more high-level care at home' and that 'meeting projected future demand will need additional investment by government beyond that currently planned'. There is a broadly similar distinction in Australia as compared to England between health and social care, comprising a 'user pays' principle in respect of social care. The King's Fund (Robertson et al 2014: 17) explains that, '[a]s in England, the Australian social care system is not universal and government assistance focuses on those with low incomes', with '[a] range of services ... offered by national and local government'. Again as in England, wealthier people often pay the full cost of their care out of pocket, up to the government-defined limit, and it is difficult to buy private insurance to cover these costs (ibid: 18; Lacey 2014). In contrast to the English emphasis on deferred payment agreements, however, the Australian Government chose not to 'support' a recommendation for 'the introduction of a government-backed scheme to enable consumers to draw on the equity in their home to pay their aged care costs' (Tune 2017: 70).

As regards residential care, 'individuals make a means-tested contribution to their care costs, and pay accommodation costs and daily living expenses themselves', with regulations setting out 'a maximum amount each person can be charged for accommodation, based on their assets, and a maximum daily living charge' (Robertson et al 2014: 17-18). Carney (2014: 23) has said that '[r] esidential aged care is a small but very expensive sub-set of Australian aged care services', and it is significant that 'the majority of aged care funding is provided by government' with just under a quarter provided by consumers (Tune 2017: 89). All care home residents can be expected to pay 'a basic daily fee equivalent to 85 per cent of the basic single age pension' (Aged Care Financing Authority 2017: 18). That is all that is payable for people whose income and assets are below a certain level, but only 18.8 per cent of care home residents were otherwise fully supported in June 2016 and 55.4 per cent were classed as 'non-supported' (ibid: 21 ). It should also be 
noted that ' $[\mathrm{h}]$ ome care for the elderly is provided through the Commonwealth Home Support Program' and that '[s]ubsidies are income-tested and may require copayments from recipients' (Glover). ${ }^{14}$

Significantly for our purposes, Australia has also undertaken a capping process for care via amendments to the Aged Care Act 1997 made by the Aged Care (Living Longer Living Better) Act 2013, making for an interesting comparison. The appropriateness of the comparison continues in the next sub-section, since England and Australia share a common law heritage that combines a default principle of testamentary freedom with the possibility of court applications for discretionary provision out of an estate, albeit that Australian States and Territories recognise care much more explicitly within that system.

It has been said that the aim of the 'living longer, living better' programme embodied in the Australian 2013 Act is 'to build a better, fairer, more sustainable and more nationally consistent aged care system' (Trurong 2013). In the aged care reforms, there is

a strong emphasis to make it easier for older Australians to stay in their home while they receive care and a removal of the distinction between low and high aged care services, along with a tighter means test to assess home care and residential care fees (ibid).

There are fears that 'part-pensioners and self-funded retirees may end up paying higher fees' (ibid), the latter of which is clearly reflected in England. But in Australia there is now (as of July 2018) both an annual cap of $\$ 26,964.71$ and a lifetime cap of $\$ 64,715.36$ (Department of Health (Australia) 2018). Those capping arrangements are applicable to all residents entering into permanent residential aged care on or after 1 July 2014, but there also appears to be an equivalent lifetime cap in the income-tested care fee for those receiving care in their own homes and a variable annual cap (Tune 2017: 84). It is significant that the lifetime cap (approximately $£ 35,770.12$ on the July 2018 value) is similar to the cap suggested by the Dilnot Commission in England, and superficially much lower than the $£ 72,000$ originally suggested by the Government there. Significantly, '[n]either basic daily fees nor accommodation costs are counted towards the annual and lifetime caps' (ibid), displaying similar limitations likely to be applied to any cap likely to be implemented in England. Again similarly to England, only a small percentage of permanent residents (specifically 5-6 per cent) are expected to reach the cap in Australia (ibid).

There is now a combined asset and income test for those in residential care in Australia (Tune 2017: 72). McCullagh (2014: 71) also asserts that 'most ordinary assets are included' in a residential care assessment, 'but not the value of the former home if still occupied by a partner (or certain carers or relatives) when entering care.' Occupation by certain people can cause the home to be disregarded in England (Sloan 2017), although it has been seen that the extent to which it

\footnotetext{
${ }^{14} c f$ Tune (2017: 19) on Victoria and Western Australia.
} 
should be disregarded in relation to domiciliary care has been the subject of much political debate there. In Australia, only income (and not capital assets, except when deemed to be income) are assessed for the purposes of domiciliary care, and Tune (2017: 71) described this as 'appropriate', since the inclusion of the home might jeopardise the care recipient's ability to remain in it and thwart a key purpose of the Act. It seems that the value of the home to be counted in the assessment is largely capped at $\$ 165,271.20$ (as of July 2018) in Australia where included (Department of Health (Australia) 2018), although Tune (2017: 80) recommended that the full value be included (where it is not excluded by virtue of a 'protected person').

While there are significant similarities between social care in England and Australia, not least that both are subject to a means test and are distinct from health care, more health care appears to be subject to patient contributions in Australia by virtue of the Medicare system. ${ }^{15}$ As Carney (2014: 19-20) puts it, 'Australia operates a publicly funded, universal system of medical benefits known as Medicare, principally funded by the federal government', albeit via a levy imposed on taxpayers in a certain income bracket. Medicare 'reimburses medical providers a "scheduled fee" component of medical costs, and funds state and territory governments under a cost-sharing agreement to provide hospitals and other infrastructure. The percentage of the fee reimbursed varies according to the cost and type of medical treatment.

Conversely, the National Disability Insurance Scheme (NDIS) could be an important source of support in Australia. ${ }^{16}$ The scheme, piloted in 2013 by the federal Government in partnership with States, seeks to 'provide more-flexible funding support (not means-tested), allowing greater tailoring of services' (Glover). The aim of the NDIS is to 'provide no-fault insurance cover for Australians who are born with or acquire a severe or profound disability' (Green and Mears 2014: 25). One description is that ' $[\mathrm{u}]$ nder the NDIS, anyone under the age of 65 and with a disability that is permanent, or likely to become permanent, and significant will be eligible for the NDIS,' subject to immigration status (Cebulla and Zhu 2016: 257). ${ }^{17}$ Funding for the NDIS was provided by an increase in the Medicare levy (Walsh and Johnson 2013).

Windholz (2014: 89) has said that the NDIS 'revolutionises the provision of services to persons with disabilities', and that ' $t$ the cornerstone of the scheme ... is the provision to persons with disabilities of greater choice and control over the support they receive. The system appears similar to NHS Continuing Healthcare, albeit on a more generous scale, with an emphasis on personalisation.

It therefore seems that there is an attempt to distinguish age- from disabilityrelated care in Australia, more so than within England. Wark (2015: 93-96)

\footnotetext{
${ }^{15}$ Health Insurance Act 1973; Minford (2001).

${ }^{16}$ National Disability Insurance Scheme Act 2013.

${ }^{17}$ See further National Disability Insurance Scheme Act 2013, s 22.
} 
asserts that 'the issue of ageing with a disability does not appear to have been appropriately considered in the ... NDIS legislation', such that ' $[t]$ here remains a divide between aged-care support options predominantly funded by the Commonwealth Government and disability services auspiced through the various states'. He asserts that

$[\mathrm{u}]$ nder the NDIS legislation, individuals with disability who are ageing will be able to maintain their disability support programs or can convert to the mainstream aged-care support model once they reach 65 years of age, but the policy framework indicates that a person must choose one system or the other, as supplementary funding support to address emerging needs associated with ageing is not possible.

He thus claims that ' $\mathrm{t}$ ] he integration between the social and healthcare systems in the UK and Ireland was better managed than in Australia, although it has been seen that the relationship between the NHS and social care has created significant issues. There are fears that

[t] he introduction of the ... NDIS ... with its principle of entitlement to services based on need means that specialist disability services may be more freely available to younger people than to older Australians (those aged 65 or older) with the same disability and need. (National Aged Care Alliance, 2016: 5)

Similarly to the situation in England,

[ $\mathrm{t}$ ]he different roles and responsibility for medical, ageing and disability related aids and equipment continues to confuse consumers, whose eligibility, access and out-of-pocket costs will differ depending on where they live, their age and which service system they are able to access. (ibid: 28 )

Whatever the differences of detail, there are thus a number of common themes within the Australian and English systems: means-tested social care systems in broad contrast to health care systems, with wealthy people expected to contribute significant amounts to their care, credible allegations of discrimination and inequity of provision within the system, and an attempt to personalise services (Glover). The common feature that will form the background of the remainder of this chapter, however, is the sense that there should be some limitation on the amount that any individual should be expected to pay for her formal care, even if this feature is in some doubt in England, and even though Tune (2017: 9) when reviewing the Australian 2013 Act recommended that the annual and lifetime caps for fees should be abolished' to 'ensure that consumers contribute to the costs of their care commensurate with both their care needs and relative financial capacity'. He was concerned that ' $t$ ] he caps limit the amount that wealthier consumers contribute to their care costs, after which taxpayers effectively subsidise the full cost of their care' (ibid: 84), albeit that in England such arguments have been met with objections relating to the possibility that catastrophic costs will be imposed on some people and that discrimination will operate between those who require different types of care. The next section will consider the recognition of informal care in private law. 


\section{Informal Care}

\section{A. England}

Despite the existence of a social care system, there are around 5.8 million informal carers in England and Wales (Office for National Statistics 2013). Such carers vitally provide support to elderly and disabled people in the absence of a contractual or other legal duty to do so, ${ }^{18}$ and the majority of elderly people receiving care in their own homes do so from family members (Pickard 2015). The reasons for this are likely to include the social care system being unable to provide the required support, the costs associated with social care (discussed in the last section), and resistance to leaving one's home and/or 'official' involvement in one's care (Sloan 2013: chapter 1). The Government seems to have accepted that some responsibility for care should, or at least will inevitably, rest with family members (Swinford 2017; Sloan 2015; Conservatives 2017: 60), particularly in the aftermath of the much-anticipated 'Brexit' (Allegretti 2018).

Such carers do have some recognition in public law (Herring 2013), despite the fact that their work may well be located in the 'private' sphere because of its nature. The Care Act 2014, for example, created 'the first ever entitlement to support for carers' (Department of Health 2014a). My previous work, however, has considered the extent to which carers do or should nevertheless have a claim against the property and/or estate of a care recipient in recognition of their efforts and the fiscal and health disadvantages that they suffer (Sloan 2013 and 2015), and an aim of this chapter is to assess whether such a claim is appropriate in light of the possible moves towards limiting liability of care recipients to pay for formal care. This will be placed in the context of the wide recognition of caring relationships in Australian private law, addressed in the next sub-section.

Proprietary estoppel is an equitable doctrine that has been used to facilitate claims by informal carers against care recipients or their estates (McFarlane 2014). An estoppel claim arises where:

The owner of land [or other property], A, in some way leads or allows the claimant, B, to believe that he has or can expect some kind of right or interest over A's [property]. To A's knowledge, B acts to his detriment in that belief. A then refuses B the anticipated right or interest in circumstances that make that refusal unconscionable (HM Land Registry and Law Commission: [5.29]).

Lord Walker (2008: 234) has said that '[i]n modern authorities the [estoppel] claimant's case is usually founded ... on [his] personal assistance to the defendant', and there have been a number of successful estoppel claims involving informal

\footnotetext{
${ }^{18}$ See Herring (2013: ch 2) for a discussion of the difficulties relating to definitions in this context.
} 
carers (Sloan 2013: chapter 2). Claims are often brought after the death of the representor, for example on the basis that the care recipient promised to leave property to the claimant in a will but failed (whether accidentally or deliberately) to do so.

Proprietary estoppel is controversial because of uncertainties surrounding its requirements, and because it circumvents the usual restrictions placed upon a valid contract, a valid disposition of an interest in land and a valid will (ibid; Dixon 2010). ${ }^{19}$ It is nevertheless well-established, and does provide a remedy for some carers. That said, the doctrine is limited to the enforcement of promises or expectations somehow generated by the care recipient. ${ }^{20}$

It might be assumed that a remedy could readily be sought by an informal carer on the basis that the care recipient was unjustly enriched by the services provided (Nield 2007). Even so, the possibility of using the principles of unjust enrichment to claim a remedy for caring or other domestic services, such as a quantum meruit calculated according to their reasonable value, ${ }^{21}$ remains controversial in England (Sloan 2013: chapter 4). ${ }^{22}$ It is relatively well-established that, in England, a successful unjust enrichment claim involves the enrichment of the defendant at the expense of the claimant in particular circumstances rendering the enrichment unjust and where there are no defences. ${ }^{23}$

Even if it can be shown that the care recipient was enriched at his expense (Sloan 2013: chapter 4), the claimant carer must still identify the relevant unjust factor through which restitution of unjust enrichment can be sought. ${ }^{24}$ This is not an easy task, and Wells (2007: 69) argues that that the courts have not always scrupled to identify the unjust factor present in more recent quantum meruit cases. Several factors could be relevant (Sloan 2013: 124-28), but a fundamental difficulty faced by the carer who seeks a remedy is that in many situations he can plausibly be described as a 'domestic risk-taker' (Mee 2009: 374). ${ }^{25}$ In other words, it could often be said that he voluntarily assumed caring responsibilities without entering a contract, and 'gambled' (Burrows 1988) on the care recipient's

\footnotetext{
${ }^{19}$ On the advantages of the statutory approach of the Law Reform (Testamentary Promises) Act 1949 in New Zealand, see, eg, Sloan (2013: ch 3).

${ }^{20}$ cf Sloan (2013: ch 8).

${ }^{21} c f$, eg, Havelock (2016).

${ }^{22} \mathrm{cf}$ the antiquated cases on the provision of urgent medical treatment for 'paupers', eg, Lamb $v$ Bunce (1815) 4 M \& S 275, (1815) 105 ER 836 (KB).

${ }^{23}$ Banque Financière de la Cité v Parc (Battersea) Ltd [1999] 1 AC 221 (HL), 227 (Lord Steyn). cf Investment Trust Companies (In Liquidation) $v$ Revenue and Customs Commissioners [2012] EWHC 458 (Ch); $c f$ Birks (2005) on 'absence of basis' as the justification for an unjust enrichment claim. For a discussion of possible defences to an unjust enrichment claim, see, eg, Mitchell, Mitchell and Watterson (2016: part 6).

${ }^{24}$ See, eg, Deutsche Morgan Grenfell v Inland Revenue Commissioners [2006] UKHL 49 [21] (Lord Hoffmann).

${ }^{25}$ For a devastating critique of the language of 'risk-taking' in the law of unjust enrichment, see Wilmot-Smith (2011).
} 
willingness to pay for his services after the event. Virgo (2015: 36-37) considers it a fundamental principle that where a claimant has acted officiously in transferring a benefit, the law of unjust enrichment will not come to his aid. ${ }^{26}$

It can be concluded that a carer is likely to encounter difficulty in utilising the English law of unjust enrichment at present. Walsh $v$ Singh, ${ }^{27}$ a case involving the property and business affairs of former fiancés, could be illustrative of the current attitude of the English judiciary to the use of unjust enrichment in the domestic context. Without discussing particular unjust factors, Judge Purle QC expressed concern that

[i]f dashed expectations of a long-term domestic relationship open the door to unjust enrichment claims, a wide range of claims which the concept of unjust enrichment was never meant, and is ill equipped, to deal with will come marching through. ${ }^{28}$

It may be possible to distinguish care cases from Walsh $v$ Singh, but it is conceivable that Judge Purle QC's more general statement will become influential.

Succession law is a possible basis of claim for an informal carer, although the basic principle of English succession law is that that 'an Englishman still remains at liberty at his death to dispose of his own property in whatever way he pleases. ${ }^{29}$ No family member or carer of any sort has an inherent right to provision from an estate. That said, the Inheritance (Provision for Family and Dependants) Act 1975 allows certain people to seek discretionary provision out of the estate (Sloan 2017a: chapter 9). One such category (in section 1(1)(e) of the Act) is a person who was maintained by the deceased, even if he did not have another familial or conjugal relationship with the deceased. Early section 1(1)(e) case law was prejudicial to carers because care was considered 'full valuable consideration' for the carer's maintenance, which eliminated the claim. ${ }^{30}$ While amendments to the Act now make clear that 'full valuable consideration' applies only to arrangements of a commercial nature, ${ }^{31}$ the category is inherently premised on a requirement that the deceased (care recipient in our context) maintained the claimant (carer) rather than the other way around.

Adult children ${ }^{32}$ and people whom the deceased treated as a 'child of the family' notwithstanding they were not legal children of the deceased ${ }^{33}$ are also included among the categories of applicant, albeit that (in common with those who are not spouses or civil partners of the deceased $)^{34}$ they must show that 'the

\footnotetext{
${ }^{26}$ See also, eg, Deutsche Morgan Grenfell v Inland Revenue Commissioners [2006] UKHL 49, at [25]-[27] (Lord Hoffmann).

${ }^{27}$ Walsh $v$ Singh [2009] EWHC 3219 (Ch).

${ }^{28}$ ibid [67].

${ }^{29}$ Re Coventry (decd) [1980] Ch 461, 474 (Oliver J).

${ }^{30}$ Inheritance (Provision for Family and Dependants) Act 1975, original s 1(3); see, eg, Re Wilkinson (deceased) [1978] Fam 22.

${ }^{31}$ Inheritance (Provision for Family and Dependants) Act 1975, s 1(3), as amended by the Inheritance and Trustees' Powers Act 2014.

${ }^{32}$ Inheritance (Provision for Family and Dependants) Act 1975, s 1(1)(c).

${ }^{33}$ Inheritance (Provision for Family and Dependants) Act 1975, s 1(1)(d).

${ }^{34} c f$ Inheritance (Provision for Family and Dependants) Act 1975, s 1(2)(a)-(aa).
} 
disposition of the deceased's estate effected by his will or the law relating to intestacy, or the combination of his will and that law, is not such as to make reasonable financial provision' for the applicant's maintenance. ${ }^{35}$ In deciding both whether this is the case and what provision should be made, the court will take into account a wide range of factors. ${ }^{36}$

Of course, many carers will be able to demonstrate a relevant need for maintenance that might justify provision from the former care recipient's estate, ${ }^{37}$ and one of the strongest justifications for a private law remedy is that the carer will have suffered disadvantages generating such a need (Sloan 2013: chapter 5). The leading case on the 1975 Act, however, is the Supreme Court's recent decision is Ilott $v$ The Blue Cross. ${ }^{38}$ It involved a claim by a daughter who had been estranged from her mother for some 26 years before the mother's death. The daughter and her family were dependent on state benefits, but had her substantial award reduced back to $£ 50,000$ by the Supreme Court. Significantly, Lord Hughes contrasted the facts of the current case with a hypothetical one involving a

claimant ... child of the deceased who had remained exceptionally and confidentially close to her mother throughout, had supported and nurtured her in her old age at some cost in time and money to herself, and ... had been promised many times that she would be looked after in the will. ${ }^{39}$

While 'adhering to the concept of maintenance', he opined that 'a judge ought in such circumstances to attach importance to the closeness of the relationship in arriving at his assessment of what reasonable financial provision requires. ${ }^{40}$ That said, he was also anxious that 'care must be taken to avoid making awards under the 1975 Act primarily rewards for good behaviour on the part of the claimant or penalties for bad on the part of the deceased.' ${ }^{41}$ The requirement to show a need for maintenance inevitably means that some carers will be unable to secure any provision even if they fall within an eligible category of applicant.

Given that English Law is already content to interfere with testamentary freedom for several reasons and for a wide range of applicants (Herring 2016a), reform in this area should be seriously considered.

In contrast to the wide range of applicants who can claim statutory property or financial provision from an estate, only (at least purported or former) spouses (who can be any combination of genders) ${ }^{42}$ or same-sex civil partners, ${ }^{43}$ and

\footnotetext{
${ }^{35}$ Inheritance (Provision for Family and Dependants) Act 1975, ss 1(1), 1(2)(b).

${ }^{36}$ Inheritance (Provision for Family and Dependants) Act 1975, s 3.

${ }^{37}$ See, eg, Re Jennings [1994] Ch 286 (CA), 300; Estate of McGarrell [1983] 8 NIJB; Re Callaghan (deceased) [1985] Fam 1.

${ }^{38}$ Ilott v The Blue Cross [2017] UKSC 17, [2018] AC 545. See, generally, Sloan (2019).

39 [2017] UKSC 17 [35].

${ }^{40} \mathrm{ibid}$.

41 ibid [47].

${ }^{42}$ See, eg, Matrimonial Causes Act 1973, Part II.

${ }^{43}$ See, eg, Civil Partnership Act 2004, sch 5.
} 
usually minor children (or at least those still in education) ${ }^{44}$ can claim similar provision while the defendant is still alive (Sloan 2013: chapter 6). As might be expected, those within the prohibited degrees of relationship (including parents and children) are prevented from entering a valid marriage or civil partnership, ${ }^{45}$ notwithstanding the attempt to remove the degrees from the Civil Partnership Bill as it passed through Parliament (Glennon 2005). ${ }^{46}$ Moreover, child support plays a very limited role once the child in question reaches 18 (Masson, Bailey-Harris and Probert 2008: [15-032]). The prospects for a caring adult child bringing a successful inter vivos statutory claim are therefore very slight and they are essentially non-existent for other non-spouses/civil partners. It should be noted that even conjugal cohabitants are denied such a statutory claim in their own right (Sloan 2015a), and changing this may well be seen as a priority (Law Commission 2002 and 2006).

The focus on conjugality and countervailing failure to prioritise care per se in English family law has been criticised (Herring 2013: chapter 6), and is not consistent with all other jurisdictions (including in Australia, as will be seen in the next sub-section). That said, statutory inter vivos claims by carers may not reflect public expectations (Peart 2008), ${ }^{47}$ and bring additional difficulties as compared to succession-based claims in light of the care recipient's continued need of her property and the awkwardness that such a claim might cause within a caring relationship (Sloan 2013: 138-39). The recognition of caring relationships in Australia ought now to be considered.

\section{B. Australia}

As in England, despite the availability of social care, informal carers play a vital role in Australia. It has been said that ' $[\mathrm{m}]$ ost aged care is informal, provided by families, friends, communities and volunteers' (Tune 2017: 6), and one study found that 92 per cent of 'people living in their own homes with severe or profound limitations in core activities receive informal care', with '[t]hirty-eight percent receiv[ing] only informal assistance and 54 percent receiv[ing] a combination of informal and formal assistance' (Glover). Conversely, '[a]pproximately 2.3 million people provide some informal care of the aged' and '[i]n 2009, 12 percent of Australians were informal caregivers and around 30 percent of those were the primary caregiver [carer]'.

\footnotetext{
${ }^{44}$ Child Support Act 1991; Children Act 1989, sch 1.

${ }^{45}$ Matrimonial Causes Act 1973, s 11(a)(i); Civil Partnership Act 2004, s 3(1)(d).

${ }^{46}$ A similar attempt was made while the Marriage (Same Sex Couples) Bill passed through: Hansard, 24 June 2013, Volume 746, Cols 525-547.

${ }^{47} c f$ Briggs (2015: 670).
} 
Public state support for carers is available, for example in the form of the 'carer payment' and 'carer allowance' and covering both children and adults. ${ }^{48}$ In 2011-12, the federal government 'provided AUD3.18 billion (USD2.07 billion) under the income-tested Carer Payment program, and AUD1.75 billion (USD1.14 billion) through the Carer Allowance (not income-tested, and offered as a supplement for daily care)' (Glover). The Government 'also provides an annual Carer Supplement of AUD480 million (USD313 million) to help with the cost of caring'.

In a number of Australian States and Territories, however, caring relationships are recognised on a similar basis to other adult relationships, such as marital or de facto (ie conjugal cohabitational) ones. This includes recognition in succession law (National Committee on Uniform Succession Laws 2004: 7 fn 42), in contrast to the piecemeal and non-tailored approach of English Law considered above. On Wong's (2009: 53) account, the Australian Capital Territory's Domestic Relationships Act 1994 was 'the first sub-national legislation to shift the focus of domestic relationships from status to interdependency'. It was described as 'representing a movement towards a more fluid concept of relationships governed by redistributive law, ${ }^{49}$ including non-couple relationships where care and support was present. ${ }^{50}$ Other Australian States and Territories have similarly gone further than England and Wales by specifically recognising the relationship between carer and care recipient on a basis similar to that between conjugal couples (married or unmarried). ${ }^{51}$

The New South Wales concept of a 'close personal relationship', introduced in $1999^{52}$ and now governed by the Succession Act 2006 in the succession law context, ${ }^{53}$ would provide something of a solution to the problems currently faced by carers under the English 1975 Act (and private law in general). It is apparently backward- rather than forward-looking, at least as regards eligibility, ${ }^{54}$ which means that a 'pure' carer without another relationship with the care recipient is nevertheless likely to fall within the parameters of the category based on what he has done for the deceased in the past.

A 'close personal relationship' exists

between two adult persons [who are not in a marriage or de facto relationship with each other], whether or not related by family, who are living together, one or each of whom provides the other with domestic support and personal care. ${ }^{55}$

\footnotetext{
${ }^{48}$ Social Security Act 1991, Part 2.5.

${ }^{49}$ McKenzie v Storer [2007] ACTSC 88 [57] (Stone J).

${ }^{50}$ Domestic Relationships Act 1994 Act (ACT), s 3.

${ }^{51}$ See, eg, Relationships Amendment (Caring Relationships) Act 2009 (Vic).

${ }^{52}$ Property (Relationships) Legislation Amendment Act 1999 (NSW).

${ }^{53}$ cf Family Provision Act 1982 (NSW), s 6(1)(a)(ii).

${ }^{54}$ cf Sloan (2013: section 5.4.10).

${ }^{55}$ Succession Act 2006 (NSW), s 3(3) (as amended).
} 
A claim is precluded, however, if the domestic support or personal care is provided 'for fee or reward' or 'on behalf of another person or an organisation (including a government or government agency, a body corporate or a charitable or benevolent organisation). ${ }^{56}$ The 'close personal relationship' must exist at the time of death.

One restriction in the amended Succession Act 2006 is that applicants who invoke the 'close personal relationship' provision are not eligible as of right, and must convince the court that 'having regard to all the circumstances of the case (whether past or present) there are factors which warrant the making of the application. ${ }^{57}$ In relation to other claimant categories, the courts require 'good and sufficient grounds for the application. ${ }^{38}$ A significant amount of care should constitute a factor warranting the application, not least because it has been allowed to do so in applications by dependants. ${ }^{59}$ Significantly, in Estate MPS, there were said to be 'factors warranting' an application despite the fact that the 'care' provided was held to be 'inappropriate and inadequate, ${ }^{\text {' }}{ }^{2}$ which arguably raises issues concerning what might be called the 'dark side' of care.

Interestingly, the court is permitted to have regard to the same list of factors when determining whether an applicant is an eligible person as when it is exercising its discretion on determining the relief to be granted. ${ }^{61}$ This discretionary approach appears open-ended. ${ }^{62}$

The 'close personal relationship' is composed of a number of elements. Notwithstanding the fact that the deceased and the applicant must have been 'living together', in Hayes v Marquis the Court of Appeal of New South Wales has accepted that the parties to a close personal relationship do not have to do so on a full-time basis. ${ }^{63} \mathrm{McC}$ Coll JA suggested that the common residence requirement might be 'somewhat more attenuated' for the purposes of a close personal relationship than for a de facto relationship between cohabitants. ${ }^{64}$ This is significant, since it is not strictly necessary even for de facto partners to share a household to qualify for provision in New South Wales. That said, Einstein J considered it important that the parties regard the place they live together as 'their home', even if family or work commitments sometimes required them to leave it. ${ }^{65}$ Moreover, the 'domestic support' requirement was said to underline the notion of a shared household. ${ }^{66}$

\footnotetext{
${ }^{56}$ Succession Act 2006 (NSW), s 3(4). A carer's pension is not a relevant fee or reward: Woodland $v$ Rodriguez [2004] NSWSC 1167.

${ }^{57}$ Succession Act 2006 (NSW), s 59(1)(b).

${ }^{58}$ O’Shaughnessy v Mantle (1986) 7 NSWLR 142, 146 (Young J).

${ }^{59}$ Blackley $v$ Proctor [2001] NSWSC 537; Barlevy $v$ Nadolski [2011] NSWSC 129 [199] (Slattery J).

${ }^{60}$ Estate MPS, deceased [2017] NSWSC 482 [107] (Lindsay J).

${ }^{61}$ Succession Act 2006 (NSW), s 60(1)(a).

${ }^{62} c f$ Victorian Law Reform Commission (2013: ch 6).

${ }^{63}$ Hayes v Marquis [2008] NSWCA 10 [78].

64 ibid [79].

${ }^{65} \mathrm{ibid}[166]$.

${ }^{66}$ ibid [76] (McColl JA).
} 
In Dridi v Filmore, it was confirmed that the domestic support and personal care requirements were cumulative, increasing the sense in which the legislation recognises care per se. ${ }^{67}$ There is, however, an inevitable overlap between the concepts. In Hayes, the phrase 'domestic support' was not held to 'occasion any particular questions of ambiguity'. ${ }^{\prime}$ The Attorney General, in the debates leading to the passing of the 1999 reforms, opined that such support consisted of 'attending to the household shopping, cleaning, laundry and like activities. ${ }^{69}$

The 'personal care' requirement, crucial for present purposes, has been a source of greater difficulty. The Supreme Court of New South Wales originally interpreted 'personal care' to mean 'assistance with mobility, personal hygiene and physical comfort', with the result that emotional support in itself was insufficient. ${ }^{70}$ The effect of this, according to Graycar and Millbank (2007: 149), was to turn the concept into 'one addressing only (unpaid) live-in caregivers'. The Law Reform Commission (2006: [3.10]) proclaimed that: 'The "personal care" element is not easy to satisfy.' In one case, the performance of housework and the transporting of the deceased to medical appointments was not sufficient to constitute 'personal care. ${ }^{71}$ In another, ' $[\mathrm{t}]$ he fact that the appellant provided ... support for weekly periods over ... 15 months did not constitute the relationship as one that involved the closeness or intimacy necessary for a close personal relationship. ${ }^{72}$ It is clear that a certain amount of domestic support and care is needed before the statute is engaged. In the opinion of McColl JA in Hayes, 'if two adults lived together fulltime and one provided domestic support and personal care to the other only once or twice a year, it would be difficult to say that a close personal relationship had been established. ${ }^{73}$

A carer who provides a significant level of care is unlikely to have any difficulty in satisfying the 'domestic support' and 'personal care' criteria provided he can demonstrate a sufficiently shared household. Moreover, the courts have shown themselves to be willing to infer that care has taken place. ${ }^{74}$

The Succession Act 2006 (taking up the mantle of the previous Family Provision Act 1982) is an important example of how family provision law can specifically address scenarios involving care in order to provide a remedy for informal carers. Nevertheless, although the category apparently prevents a gap in the legislation, the New South Wales Law Reform Commission (2006) reports that few cases have been brought by people in 'close personal relationships' and that such claims tend to be presented as falling within another category. This would not, however, detract

\footnotetext{
${ }^{67}$ Dridi v Filmore [2001] NSWSC 319 [104] (Master Macready).

${ }^{68}$ Hayes $v$ Marquis [2008] NSWCA 10 [167] (Einstein J).

${ }^{69}$ New South Wales Legislative Council, Parliamentary Debates, (Hansard) 13 May 1999, 228.

${ }^{70}$ Dridi v Filmore [2001] NSWSC 319 [108] (Master Macready). It was accepted, however, that such activities would 'include an element of emotional support'.

${ }^{71}$ Bogan v Macorig [2004] NSWSC 993.

${ }^{72}$ Amprimo v Wynn [2015] NSWCA 286 [79] (Meagher JA).

${ }^{73}$ Hayes $v$ Marquis [2008] NSWCA 10 [84].

${ }^{74}$ Hughes $v$ Charlton [2008] NSWSC 467 [55].
} 


\section{Brian Sloan}

from the justice served by such a provision if it were introduced in England. This is particularly true given the problems caused by the 'maintenance' point associated with dependency discussed above, and by the focus on conjugality and living in the same household in the case of cohabitants. In the previous edition of his book, Kerridge (2009: [8-79]) hints at the possible need to recognise carers specifically when he argues that a cohabitant of the deceased is in a privileged position as compared to a sibling who provides care, although he points out that such a sibling will often be provided for under the intestacy rules.

In the New South Wales context, the 'close personal relationship' category has sometimes proved vital in cases where an applicant has been unable to bring himself within one of the other categories, and it has been said it is not possible for the same two people to be in both a de facto relationship and a 'close personal relationship' simultaneously. ${ }^{75}$ In Hughes $v$ Charlton, for example, 'the evidence point[ed] to the [applicant] being a housekeeper for the deceased', and the applicant was therefore eligible only as a result of the 'close personal relationship' category. ${ }^{76}$ Admittedly, difficult definitional problems would have to be addressed, as illustrated by the New South Wales experience itself (Head 2011). Nevertheless, that is an inevitable feature of discretionary schemes regulating informal relationships and should not preclude an attempt at reform in England.

On a more principled level, the advent of a 'carer' category in England could be met with the objection that it would effectively introduce almost diametrically opposite categories of applicant into the 1975 Act. This allegation is justified to an extent, since one category would be based on the fact that the applicant was dependent on the deceased, and another is effectively based on the fact that the deceased was dependent on the applicant (albeit in a different sense). Nevertheless, the New South Wales legislature was apparently content to place both categories in its Act. It is worth noting that in the case of 'close personal relationships' the care recipient is equally eligible to bring a claim on the estate of the carer. ${ }^{77}$ This reflects the reality of interdependence that is often present between the parties to such relationships, and Herring (2007) points out that it can be difficult to determine which party is the carer and which the care recipient. ${ }^{78}$ The categories of the dependant and the party to a close personal relationship may be more consistent with each other than they first appear.

Moreover, given the repugnance expressed by some commentators about the idea that a slothful individual is more likely to succeed under the 1975 Act than an industrious one, the introduction of an opposing category could nevertheless be a positive development.

\footnotetext{
${ }^{75}$ Thompson $v$ The Public Trustee of New South Wales [2010] NSWSC 1137 [69] (Hallen AsJ).

${ }^{76}$ [2008] NSWSC 467 [47] (Macready AsJ). See also Smith v Daniels [2010] NSWSC 604.

${ }^{77}$ See, eg, Woodland $v$ Rodriguez [2004] NSWSC 1167.

${ }^{78}$ cf Wells (2007a: 319), who argues that 'the provision of caring services will frequently be a onesided arrangement'.
} 
A 'carer' category could also shift the emphasis away from maintenance and future need. Since there is not always a direct connection between work done in the past and the present need for maintenance, the new category could be more about remuneration. This echoes the emphasis on desert present in some of Fineman's (2004) writings. ${ }^{79}$ If the sole aim of statutory family provision is to allow the continuation of maintenance, a new category is not necessarily consistent with it. On the other hand, if the aim of such statutes could be reformulated as the encouragement and fostering of domestic support in general, a 'carer' category would simply extend this aim to include the provision of such support before death.

Unfortunately, the English Law Commission (2011: [6.92]) purposely rejected the inclusion of carers as a specific category of family provision applicant in their recent report on intestacy and family provision. It argued that outside cases of carers who were maintained by the deceased (who would be able to apply under the existing legislation), there are difficulties in 'identifying precisely who was to benefit and why'. Examples of problems given by the Commission are the level of care required (and how much entitlement it would bring), and the correct approach where another family member or friend was prevented from caring by the applicant. These are significant issues, but it is not clear that the relevant amount of care is any more difficult a question than the extent to which the deceased maintained an applicant or treated him as a child of the family (already crucial aspects of English family provision law). Moreover, the quantum of provision is separated from eligibility throughout the rest of the Act, and it is surprising that the Law Commission conflated the two matters as regards carers. Given that New South Wales and other jurisdictions have found methods of including carers within family provision, it is regrettable that the Commission did not explicitly adopt a comparative approach when swiftly rejecting the specific inclusion of carers.

As well as bringing a family provision claim, parties to 'close personal relationships' in New South Wales can secure orders to redistribute property if the relationship breaks down while both parties are still alive. ${ }^{80}$ In spite of these inter vivos remedies, according to the Law Reform Commission (2006: [3.22]),

[i]n most cases, such relationships are likely to end with the death of the person being cared for, in which case the person who has taken care of the other may have recourse against the estate if they feel they were not adequately provided for.

Hayes $v$ Marquis involved an inter vivos claim in which the parties were held to be in a 'close personal relationship'. Nevertheless, it is significant that the relationship later met the criteria for a 'de facto' relationship. ${ }^{81}$

\footnotetext{
${ }^{79}$ cf Fineman (2008).

${ }^{80}$ Property (Relationships) Act 1984 (NSW); See New South Wales Law Commission (2006: [3.26]-[3.35]) for discussion.

${ }^{81}$ See also Burgess $v$ Moss [2010] NSWCA 139.
} 
The apparent rarity of inter vivos claims in genuine care situations, even where such claims are possible, adds weight to the appropriateness of family provision law in providing a remedy for the carer. The specific advantages of succession law cannot be applied to inter vivos provision, not least because the care recipient still has need of her property and the parties do not necessarily expect their property to be regulated in such a way while they are still alive. An approach based on family provision is therefore a preferable remedy, even if an inter vivos solution has the potential advantage of remedying the detriment suffered by the carer at an earlier stage.

The Relationships Act 2003 (Tasmania) provides an alternative model with its concept of 'caring relationships. ${ }^{82}$ These are defined using similar terms to the New South Wales 'close personal relationships', but with a non-exhaustive checklist to aid in determining whether a 'caring relationship' exists. ${ }^{83}$ The Act similarly enables those in caring relationships to apply for property adjustment and maintenance on the breakdown of their relationships. ${ }^{84}$

Caring relationships can be registered in Tasmania. ${ }^{85}$ Registration is conclusive as regards the existence of the relationship, ${ }^{86}$ eliminating the need to resort to the checklist. The registration of a relationship also permits access to a wider range of benefits than if it is unregistered, and still more benefits remain reserved for registered couples in a conjugal relationship (Graycar and Millbank 2007). Independent legal advice is required before registration can occur, ${ }^{87}$ and it must relate to both 'the effect of the registration ... on the rights of the parties' 88 and 'the advantages and disadvantages, at the time that the advice was provided, to the party of registering a deed of relationship. ${ }^{89}$ A considerable limitation is that the parties will not be able to register unless each of them can declare that he/she is unmarried and not a party to a 'significant' (ie de facto conjugal) relationship or another 'caring' relationship, whether registered or unregistered. ${ }^{90}$

In the first three years of the operation of the Tasmanian Act, no 'caring relationships' were registered (Graycar and Millbank 2007), and although Rundle (2011) records four such registrations by 2011, the Tasmanian registry of births, marriages and deaths reported no more by October $2017 .{ }^{91}$ Graycar and Millbank (2007: 150-53) suggest that the limited take-up could indicate the redundancy of the provisions, and claim that there is 'no empirical evidence to demonstrate an unmet legal need for any broadly-based recognition of

\footnotetext{
${ }^{82}$ Relationships Act 2003 (Tas), s 5.

${ }^{83}$ Relationships Act 2003 (Tas), s 5(5).

${ }^{84}$ Relationships Act 2003 (Tas), part 5.

${ }^{85}$ Relationships Act 2003 (Tas), s 11.

${ }^{86}$ Relationships Act 2003 (Tas), s 5(4).

${ }^{87}$ Relationships Act 2003 (Tas), s 11(3).

${ }^{88}$ Relationships Act 2003 (Tas), 11(3)(a).

${ }^{89}$ Relationships Act 2003 (Tas), s 11(3)(b). See Rundle (2011) for criticism.

${ }^{90}$ Relationships Act 2003 (Tas), s 11(2)(a).

${ }^{91}$ Personal correspondence with the author.
} 
non-couple relationships'. On the other hand, they also admit that lack of public information could be a factor, and many of the general problems with opt-in schemes for unmarried cohabitants are likely to apply in this context (Law Commission 2007; Scherpe 2005) alongside the inherent informality of large numbers of caring relationships.

The Tasmanian experience did not prevent Victoria from enacting a similar registration scheme in 2009. ${ }^{92}$ New South Wales, on the other hand, appears to have excluded 'close personal relationships' from its registration scheme for couples ${ }^{93}$ in spite of the Law Reform Commission's (2006) recommendations.

In any case, exclusive registration-based schemes for the recognition of carer relationships compound the general difficulties with inter vivos remedies (Sloan 2013: section 5.2; Glennon 2005: 144-45) ${ }^{94}$ It may therefore be the case that recognition for particular purposes, such as family provision law, is preferable. Whatever the particular model adopted, it seems tolerably clear that the recognition of care in private law is much more rational and tailored in Australia than it is in England.

\section{Synthesis and Conclusion}

This chapter has sought to consider the recognition and funding of formal care (broadly associated with the public sphere) and informal care (broadly associated with the private sphere) in England and Australia. It is noteworthy that both England and Australia have considered a capping process on formal care (albeit that the process is apparently complete in Australia but remains controversial there and has a particularly uncertain future in England as of September 2018), but that New South Wales (for example) is much more rational in its recognition of caring relationships, and that this was the case long before the capping process undertaken in the 2013 Act.

The scope for any successful private law claim could be increased by the needs as well as resources of a care recipient in a manner that I have suggested is undesirable in the case of formal care. That said, a distinction could perhaps be made with regard to informal care where it concerns a genuine caring relationship, whereby care is not merely a service provided by the state (funded by the anonymous taxpayer) to an individual but part of the ubiquitous exchanges involved in everyday life. The argument might run that if we are content to mandate transfers between private individuals consequent on relationships, particularly where one of the parties has died, care would be an

\footnotetext{
${ }^{92}$ Relationships Amendment (Caring Relationships) Act 2009 (Vic), amending Relationships Act 2008 (Vic).

${ }^{93}$ Relationships Register Act 2010 (NSW).

${ }^{94}$ See Rundle (2011) for a general discussion of registration schemes.
} 
appropriate principle upon which to base such transfers (Sloan 2013). This would fit with Herring's (2013; also Chapter nine this volume) advocacy of a relational approach to care. It could also be said that the mere fact that liability to pay for formal care might be limited does not mean that there should be no liability to pay for it at all, and that appropriating the unpaid labour of a devoted carer is not always a legitimate means of avoiding paying for one's care. That said, it is important that private transfers of property are not seen as an excuse for the state to abdicate its responsibilities to address the conundrum of care and provide adequately for the needs of its citizens (Sloan 2015).

\section{References}

Age UK (2016) ' $1.2 \mathrm{~m}$ older people don't get the social care they need', available online at: www.ageuk. org.uk/latest-news/archive/12m-older-people-dont-get-the-social-care-they-need/ (accessed 25 September 2017).

Aged Care Financing Authority (2017) 'Report to inform the 2016-17 review of amendments to the Aged Care Act 1997'.

Allegretti, A (2018) 'Women may have to quit jobs to fill care roles post-Brexit, report warns', Sky News (6 August 2018), available online at: news.sky.com/story/women-may-have-to-quit-jobs-to-fillcare-roles-post-brexit-report-warns-11463021 (accessed 25 September 2018).

Asthana, A (2017) 'Theresa May will not reveal social care cap before general election', The Guardian (28 May 2017), available online at: www.theguardian.com/society/2017/may/28/theresa-may-willnot-reveal-social-care-cap-before-general-election (accessed 25 September 2018).

Baxter, K (2016) 'Self-funders and social care: findings from a scoping review' Research, Policy and Planning 31: 179.

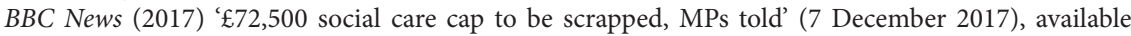
online at: www.bbc.co.uk/news/uk-politics-42266076 (accessed 25 September 2018).

Bilton, K (2014) 'Care Arrangements: Who Cares? Who Pays?' Bulletin of the Social Work History Network 1: 14.

Birks, P (2005) Unjust Enrichment, 2nd edn (Oxford, Clarendon Press).

Briggs, M (2015) 'Rethinking Relationships' Victoria University of Wellington Law Review 46: 649.

Burrows, A (1988) 'Free Acceptance and the Law of Restitution' Law Quarterly Review 104: 576.

Campbell, D (2017) 'Hammond's budget bows to demands for social care cash injection', The Guardian (8 March 2017), available online at: www.theguardian.com/uk-news/2017/mar/08/hammondsbudget-bows-to-demands-for-social-care-cash-injection (accessed 25 September 2018).

Carney, T (2014) 'Where Now Australia’s Welfare Stare?' Sydney Law School Research Paper No 14/89.

Cebulla, A and Zhu, R (2016) 'Disability, and social and economic inclusion: who is in and out of the Australian National Disability Insurance Scheme?' Scandinavian Journal of Disability Research 256.

Commission on Funding of Care and Support (2011) Fairer Care Funding.

Conservatives (2017) 'Our Manifesto', available online at: www.conservatives.com/manifesto (accessed 25 September 2018).

Department of Health (2015) The Care Act 2014: Consultation on Draft Regulations and Guidance to Implement the Cap on Care Costs and Policy Proposals for a New Appeals System for Care and Support.

- (2014) Review of Care Products - Key Messages.

(2014a) Factsheet 2.

(2018) 'Care and Support Statutory Guidance', available online at: www.gov.uk/guidance/careand-support-statutory-guidance (accessed 25 September 2018). 
Department of Health (Australia) (2018) 'Schedule of Fees and Charges: From 1 July 2018', available online at: agedcare.health.gov.au/sites/g/files/net1426/f/documents/06_2018/schedule_of_fees_and_ charges_for_residential_and_home_care.pdf (accessed 25 September 2018).

Dixon, M (2010) 'Confining and Defining Proprietary Estoppel: The Role of Unconscionability' Legal Studies 30: 408.

Elgot, J (2017) 'We cannot afford to fund “dementia tax" proposals, councils warn', The Guardian (17 October 2017), available online at: www.theguardian.com/society/2017/oct/17/we-cannotafford-to-fund-dementia-tax-proposals-councils-warn (accessed 25 September 2018).

Fernández, J-L and Nadash, P (2016) 'The Long-term Care Financing Problem' in C Gori et al (eds), Long-term Care Reforms in OECD Countries: Successes and Failures (Bristol, Policy Press).

Fineman, MA (2004) The Autonomy Myth: A Theory of Dependency (New York, New Press).

- (2008) 'The Vulnerable Subject: Anchoring Equality in the Human Condition' Yale Journal of Law and Feminism 20: 1.

Full Fact (2017) 'The adult social care spending gap', available online at: fullfact.org/health/adult-socialcare-spending-gap/ (accessed 25 September 2018).

Glover, L 'The Australian Health Care System' (Commonwealth Fund), available online at: international.commonwealthfund.org/countries/australia/ (accessed 25 September 2018).

Graycar, R and Millbank, J (2007) 'From Functional Family to Spinster Sisters: Australia’s Distinctive Path to Relationship Recognition' Washington University Journal of Law and Policy 24: 121.

Green J and Mears, J (2014) 'The Implementation of the NDIS: Who Wins, Who Loses?' Cosmopolitan Civil Societies Journal 6(2): 3915.

Havelock, R (2016) 'A Taxonomic Approach to Quantum Meruit' Law Quarterly Review 132: 470.

Glennon, L (2005) 'Displacing the Conjugal Family in Legal Policy - A Progressive Move?' Child \& Family Law Quarterly 17: 141.

Head, A (2011) 'The Legal Recognition of Close Personal Relationships in New South Wales - A Case for Reform’ Flinders Law Journal 13: 53.

HM Government (2017) 'The Queen's Speech and Associated Background Briefing, on the Occasion of the Opening Of Parliament On Wednesday 21 June 2017' (Crown).

HM Land Registry and Law Commission (2001), Land Registration for the Twenty-First Century: A Conveyancing Revolution (Law Com No 271).

Herring, J (2007) 'Where are the Carers in Healthcare Law and Ethics?' Legal Studies 27: 51.

- (2013) Caring and the Law (Oxford, Hart Publishing).

(2016) Medical Law and Ethics, 6th edn (Oxford, Oxford University Press).

(2016a) 'Will-Substitutes and the Claims of Family Members and Carers' in A Braun and A Röthel (eds), Passing Wealth on Death: Will-Substitutes in Comparative Perspective (Oxford, Hart Publishing).

Hopkins, N and Laurie, E (2015) 'Social Citizenship, Housing Wealth and the Cost of Social Care: Is the Care Act 2014 "Fair"?' Modern Law Review 78: 112.

Hughes, M (2004) 'Privacy in Aged Care’ Australian Journal of Ageing 23: 110.

Independent Age and Institute and Faculty of Actuaries (2017) Will The Cap Fit?

Institute and Faculty of Actuaries (2014) How Pensions Can Help Meet Consumer Needs under the new Social Care Regime.

- (2015) How Financial Products Can Work Alongside the Care Act 2014 to Help People Pay for Care: An Overview.

Jarrett, T (2018) 'Social care: forthcoming Green Paper on older people and parallel programme (England)' (House of Commons Library Briefing Paper Number 8002).

Kelly, D (2013) 'Editorial: Reflecting on the Implications of the Care Act 2014 for Care Providers' Journal of Care Services Management 7: 74.

Kerridge, R (2009) Parry and Kerridge: The Law of Succession, 12th edn (London, Sweet \& Maxwell).

King's Fund (2014) A New Settlement for Health and Social Care: Final Report.

Lacey, W (2014) 'Neglectful to the Point of Cruelty? Elder Abuse and the Rights of Older Persons in Australia' Sydney Law Review 36: 99. 


\section{Brian Sloan}

Law Commission (2002) Sharing Homes: A Discussion Paper (Law Com No 278).

- (2006) Cohabitation: The Financial Consequences of Relationship Breakdown. A Consultation Paper, (Law Com No 179).

(2007) Cohabitation: The Financial Consequences of Relationship Breakdown (Law Com No 307).

- (2011) Intestacy and Family Provision Claims on Death (Law Com No 331).

Masson, J, Bailey-Harris, R and Probert, R (2008) Cretney's Principles of Family Law, 8th edn (London, Sweet \& Maxwell)

Mayhew, L and Smith, D (2014) 'Personal Care Savings Bonds: A New Way of Saving Towards Social Care in Later Life' Geneva Papers 39: 668.

McCullagh, R (2014) 'Aged Care Reforms: The Residents' Perspective' LSJ: Law Society of NSW Journal 4: 70.

McFarlane, B (2014) The Law of Proprietary Estoppel (Oxford, Oxford University Press).

Mee, J (2009) 'The Limits of Proprietary Estoppel: Thorner v Major' Child \& Family Law Quarterly 21: 374

Minford, M (2001) 'The Boundaries Between Health and Social Care for Older People in Developed Countries' (Nuffield Trust).

Mitchell, C, Mitchell, P and Watterson, S (2016) Goff \& Jones: The Law of Unjust Enrichment, 9th edn (London, Sweet \& Maxwell).

National Aged Care Alliance (2016) 'Improving the Interface Between the Aged Care and Disability Sectors'.

National Committee on Uniform Succession Laws (2004) Family Provision: Supplementary Report to the Standing Committee of Attorneys General (Queensland Law Reform Commission Report No 58, Brisbane).

New South Wales Law Reform Commission (2006) Relationships (Report No 113).

Nield, S (2007) 'Testamentary Promises: A Test Bed for Legal Frameworks of Unpaid Caregiving' Northern Ireland Legal Quarterly 58: 287.

Office for National Statistics (2013) 'More than 1 in 10 Providing Unpaid Care as Numbers Rise to 5.8 Million', BBC News, 15 February 2013: https://www.bbc.co.uk/news/health-21471544.

Paying for Care, 'Care home fees', available online at: www.payingforcare.org/care-home-fees (accessed 19 December 2017).

Peart, N (2008) 'De Facto Relationships (or Maybe Not) in New Zealand' International Family Law 130.

Pickard, L (2015) 'A growing care gap? The supply of unpaid care for older people by their adult children in England to 2032' Ageing and Society 35: 96.

Robertson, $\mathrm{R}$ et al (2014) The social care and health systems of nine countries (King's Fund).

Rundle, O (2011) 'An Examination of Relationship Registration Schemes in Australia' Australian Journal of Family Law 25: 121.

Scherpe, JM (2005) 'The Legal Status of Cohabitants - Requirements for Legal Recognition' in K Boele-Woelki (ed), Common Core and Better Law in European Family Law (Antwerp, Intersentia). Sloan, B (2013) Informal Carers and Private Law (Oxford, Hart Publishing).

- (2015) 'Informal Care and Private Law: Governance or a Failure Thereof?' Canadian Journal of Comparative and Contemporary Law 1: 275.

(2015a) 'Keeping up with the Jones Case: Establishing Constructive Trusts in "Sole Legal Owner" Scenarios' Legal Studies 35: 226.

_ (2016) 'Adult Social Care and Property Rights' Oxford Journal of Legal Studies 36: 428.

(2017) 'Charges for Charges: Home Sales under the Care Act 2014' in H Conway and R Hickey (eds), Modern Studies in Property Law: Volume 9 (Oxford, Hart Publishing). (2017a) Borkowski's Law of Succession, 3rd edn (Oxford, Oxford University Press).

(2019) 'Ilott v The Blue Cross (2017): Testing the limits of testamentary freedom' in B Sloan (ed),

Landmark Cases in Succession Law (Oxford, Hart Publishing, 2019).

Spencer-Lane, T (2015) Care Act Manual, 2nd edn (London, Sweet \& Maxwell). 
Swinford, S (2017) 'Parents responsible for care of their elderly mothers and fathers as much as their own children, minister says', Daily Telegraph (31 January 2017), available online at: www.telegraph. co.uk/news/2017/01/31/parents-responsible-care-elderlymothers-fathers-much-children/ (accessed 25 September 2018).

Trurong, W (2013) 'Aged care reform: complex changes to residential aged care' IOOF TechConnect Technical bulletin, Summer.

Tune, D (2017) 'Legislated Review of Aged Care 2017' (Commonwealth of Australia).

Ungerson, C (2004) 'Whose Empowerment and Independence? A Cross-National Perspective on "Cash for Care” Schemes' Ageing and Society 24: 189.

Victorian Law Reform Commission (2013) Succession Laws: Report.

Virgo, G (2015) Principles of the Law of Restitution, 3rd edn (Oxford, Oxford University Press).

Walker, P (2018) 'Councils give cautious welcome to extra $£ 150 \mathrm{~m}$ for social care’, The Guardian (6February 2018), available online at: www.theguardian.com/society/2018/feb/06/councils-cautiouswelcome-150m-social-care-funding-uk (accessed 25 September 2018).

Walker, R (2008) 'Which Side "Ought to Win"? - Discretion and Certainty in Property Law' Singapore Journal of Legal Studies 229.

Walsh, J and Johnson, S (2013) 'Development and Principles of the National Disability Insurance Scheme' Australian Economic Review 46: 327.

Wark, S (2015) 'Ageing, end-of-life care, and the National Disability Insurance Scheme: What can we learn from overseas?' Journal of Intellectual \& Developmental Disability 40: 92.

Wells, R (2007) 'Testamentary Promises and Unjust Enrichment' Restitution Law Review 15: 37.

_ (2007a) 'Testamentary Promises: A New Approach' (PhD thesis, King's College London).

Wilmot-Smith, F (2011) 'Replacing Risk-Taking Reasoning' Law Quarterly Review 127: 610.

Windholz, E (2014) 'NDIS Beware: Pink Batts Below!' Alternative Law Journal 39: 89.

Wong, S (2009) 'Caring and Sharing: Interdependence as a Basis for Property Redistribution' in A Bottomley and S Wong (eds), Changing Contours of Domestic Life, Family and Law: Caring and Sharing (Oxford, Hart Publishing). 
